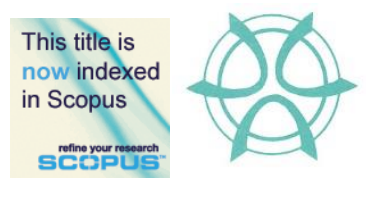

PLANNING MALAYSIA:

Journal of the Malaysian Institute of Planners

VOLUME 16 ISSUE 1 (2018), Page 360 - 371

\title{
URBAN MORPHOLOGICAL ANALYSIS FRAMEWORK FOR CONSERVATION PLANNING AND MANAGEMENT
}

\author{
Syahidah Amni Mohamed ${ }^{1}$, Nor Zalina Harun ${ }^{2} \&$ Alias Abdullah $^{3}$ \\ ${ }^{1,2}$ Institute of the Malay World and Civilization \\ UNIVERSITI KEBANGSAAN MALAYSIA \\ ${ }^{3}$ Kulliyyah of Architecture and Environmental Design \\ INTERNATIONAL ISLAMIC UNIVERSITY MALAYSIA
}

\begin{abstract}
A closer look on scientific research and professional practice concerning on the planning and management of historic towns significantly reveals the absence of integrated approaches for urban morphological analysis as a diagnostic tool to interpret the evolutionary process of its physical form. Such circumstances have influenced the transformation of urban fabric which eventually contributed to fragmented urban landscape. This study aims to provide a unifying conceptual framework represented by morphological aspects of city block as spatial units. Through a conceptual comparative approach, the framework draws upon a typomorphological approach that integrates the process typological approach and historico-geographical approach. The findings revealed that there were three main phases in construing the framework. Firstly, the pertinent basis of urban analysis can be delineated at the typological scale of city ( citta); representing by building typology at its most basic level. Consequently, to establish the interrelationship between elements of urban form, the most relevant level of resolution is on the taxonomy of sertum (block) and textus (plot series); emphasizing the representation of urban block as spatial unit. In the final phase, the inherited spatial structure of the town is unveiled according to four process of morphological region. The framework developed will ensure a clear urban form which is necessary for technical functioning and visual legibility for conservation of Early Malay town.
\end{abstract}

Keyword: typo-morphology, spatial pattern, urban block, urban landscape, early malay town 
PLANNING MALAYSIA

Journal of the Malaysia Institute of Planners (2018)

\section{INTRODUCTION}

Urban morphology in simple terms is the scientific study of urban form (Gauthier $\&$ Gilliland, 2006; Marshall, 2015). The very essence of the term 'morphology' as interpreted by Steadman $(1983 ; 1998 ; 2008)$ from Goethe's precedence (17491832) in biology is referring to the study of the structural relationships between different parts or aspects of the object to ascertain the relative of location resulted from the process of formation and transformation which shaped the overall form. In the context of the city, urban morphology analyse the relationships of the physical form, spatial structure and character of the city through four main components of urban form that apparently signifies the form of the urban fabric (Levy, 1999) which are: (i) Buildings (or constructed space); (ii) Plots or lots; (iii) Streets and (iv) Open space (Moudon, 1997; Oliveria, 2013). These components were analysed throughout its morphogenetic processes, henceforth disclosed the genesis as well as an engendering process of the city's form (Kropf, 2013).

Central to the urban morphological discourse, there seems to be an ambiguity in its theoretical and universally applicable approaches in analysing the city since the emergence of the field around 1960s led by pioneers such as Saverio Muratori and Giafranco Caniggia in Italy and M.R.G Conzen in Britain. The major challenge is to operationalize the morphological analysis in terms of acceptable practice as similar elements in the morphological studies coined differently by both scholars; however applied in parallel context with slightly difference in the level of analysis. For example, the concept of urban organism (Caniggia \& Maffei, 2001) and morphological regions (Conzen, 1960) is actually referring to the area with homogenous functions that constitutes the macro level concepts (the overall view) and significant to development process of towns.

In addition, Dibble et al. (2015) pointed out that notwithstanding the remarkable amount of effort spent by both founders and their direct descendants (see Cataldi, Maffei \& Vaccaro, 2002) revealed an absence of a unifying and quantifiable method of assessing urban form. Similar concern also raised by the international Urban Morphologist's in their discussion held in the International Seminar on Urban Form (ISUF), which has resulted to the consensus on the significant need in concluding the findings from rigorous analysis. For instance, the contribution of design theory based on traditional processes of city building as preambles to preservation effort is limited and seems to perceived on the uniqueness of the city without much emphasis on practical application (Moudon, 1997; Caliskan \& Marshall, 2011). Drawing upon the above matters, work of Kropf $(1993 ; 2009)$ proposed an integration of four existing approaches namely Spatial Analytical Approach, Configurational Approach, Process Typological Approach and Historico-geographical Approach. Despite of his attempt, the ambiguity of the morphological analysis scope is continuously debated. 
Syahidah Amni Mohamed, Nor Zalina Harun \& Alias Abdullah

Urban Morphological Analysis Framework for Conservation Planning and Management

Questions have been raised about the specific morphological approaches needed to better plan and conserve historic urban fabric. In the context of Early Malay town, albeit the significance of cultural heritage revealed in the spatial development of Early Malay town, yet current conservation practices have not often referenced to the various urban typologies. The major drawback is seen in the absence of the hierarchical level of urban form that are used for strategic planning purposes. Inevitably, this conservation-development conflict (Kong \& Yeoh, 1994) became evidence as the urban conservation efforts is isolated and confined to the preservation of single building and monument without much consideration of the contextual urban environment (Shamsuddin, 2011; Said, Aksah, \& Ismail, 2013). Consequently, specific impacts on heritage values in physical form and spatial structure presents in Early Malay town have not been correlated to these urban form typologies.

Drawing into these ambiguities, this research therefore aimed to provide an understanding on the morphological aspects of city block as spatial units and subsequently proposes an integrated and systematic framework for analytical processes. The reason for selection of city block as spatial unit is due to its unique characteristics and persistency that is developed from a smaller scale in accordance to the principles of organic growth. The study therefore, is a theoretical attempt to formulate a synthesized methodological framework for typo-morphological analysis to be applied in the context of Early Malay town. The framework proposed is therefore anticipated to provide practical conservation that considers a hierarchical structure of time-related layers of the city for conservation planning and practices that effectively respond to the urban landscape context of the city.

\section{METHODOLOGY}

The literature was drawn from research articles in journals papers accessible through online databases published between 1960 and 2017. Data were gathered largely from the International Seminar on Urban Form (ISUF) and Urban Morphology journal issues. This exploratory type of reviews attempts to identify and integrate the significant relationship with regard to the approaches and process involved within the reviewed scope of urban morphological analysis, historical city and urban conservation that are deemed relevant to be applied in the context of Early Malay towns. Through adoption of the conceptual comparative approaches, the research unveils the conceptual morphological analysis framework which draws on Caniggia and Conzen's tradition of typomorphological approaches.

In the first step to plan a system to identify the principles and methods of urban morphological analysis; i.e the relationship between building type and urban fabrics and between typology and morphology can be interpreted using synthetic model. This simplified synthetic model shows the two-way 
PLANNING MALAYSIA

Journal of the Malaysia Institute of Planners (2018)

relationships between the different primary elements of the urban fabric to emphasize their dialectical nature. Following Caniggia \& Maffei (2001) who adopts an organic approach, such relationship becomes a dynamics process of typological approach that creates pseudo-types which functionally lead to identify the basic fabric and eventually the particular fabric along the layer of hierarchy. In addition the typological process also able to link to more general mechanism of cultural transmission reflected in urban community (Table 1 and Table 2).

Further, the diachronic approach to urban form aimed to further develop an understanding on explaining the mechanisms of evolution or the process of formation and transformation of urban form. This process largely circulates around the historico-geographical approach of Conzen's (1960) town-plan analysis. The principle focuses on the plots and their aggregation in street blocks as one of the three distinct complexes of plan element according to Conzen. As a role of constant or historically persistent element in the city-level, it is represented by city block (Tale 3 ).

The integration of both types of approaches as outlined by Kropf (1993) build a theoretical foundation to develop the conceptual framework of urban morphological analysis in Early Malay town. Such integration is explicitly important as stresses by Osmond (2010), Cömert (2013), Ravari and Mazloomi (2015), and Lovra (2016). The approach considered the dynamic process of urban change evaluated from a smaller scale and through logical consequences, the structure has been gradually formed to a city which asserts an important aspect relevant for managing historic urban landscape. It is illustrated in the framework processes that are further elaborated in the findings section (Figure 1).

\section{FINDINGS: URBAN MORPHOLOGICAL ANALYSIS FRAMEWORK}

\section{Theoretical Foundation of Principles for Hierarchical City Levels}

Prior studies have noted the importance of providing a clear classification framework and basic units of morphological description. It involves some processes of selection and simplification to reflect a shared understanding of the physical and material scales at which city can be analysed (Kropf, 1993; 2013; Osmond, 2010; Ravari \& Mazloomi, 2015; Crowther, 2016) without a significant loss of the capacity of description and explanation to explain the comparison and therefore synthesis the morphological processes of the analysed city (Oliveria, 2013). This is based on the premise that "the city is the most complex of human invention" (Moudon, 1997); exposing the vast network to analyse both the physical and spatial components of the morphological elements comprised as an urban structure, all of which are part of the evolutionary processes of city development. 
Syahidah Amni Mohamed, Nor Zalina Harun \& Alias Abdullah

Urban Morphological Analysis Framework for Conservation Planning and Management

Due to the complexity of these relationships, the theoretical foundation for the urban form analyses integrated by Kropf (1993) proves to be a utilitarian instrument. The methodological frameworks established reflects an abstraction and simplification of the complexity of the urban structure using the hierarchical city layout, thus facilitates more operative system for coherent morphological analysis of the city as illustrates in Table 2. Furthermore, such classification framework through a consistent and repeatable basis of hierarchical subdivision of urban form recognized that cities are more accurately characterized as overlapping sets rather than strictly nested sets as previously epitomized in the multi-scalar system to understand the city as a patchwork of heterogeneous fragments in Collage City. Kropf's 'Taxonomy of Urban Form', Kropf (1993; 2013) made a greater comprehend on the conception of space, time and energy as basic aspects in spatial structure that have a greater relevance in the morphological analysis (Saraiva, n.d) which then should be viewed in a logic codependency based on logical connection and the relationships of part-to-part and part-to-whole among all urban elements in each hierarchical city's level for a fuller understanding of the physical materiality of the city (Osmond, 2010; Crowther, 2016)

The basic morphological principle presented primarily engage with the concept of coextensive forms which reflects the integration of Caniggia \& Maffei's (2001) approaches of spatial (or co-presence) and temporal (or derivation), implying the understanding on the formation and transformation of the city's form throughout four multiple scales. The analysis of spatial correlations proceeds from an abstract set or schema of component subdivisions that forms a hierarchy consists of: (i) Elements; (ii) Structure of Elements; (iii) System of Structures; and (iv) Organism or nucleus of city. Accordingly, this schema is then applied accordingly to: (i) Buildings; (ii) Groups of Buildings; (iii) City; and (iv) Region (Moudon, 1994). Following the principles of aggregation as the very basic phenomena for the hierarchical subdivision structure of elements and operated with a sense of modularity; the forms identified at the different levels recognised as types; giving emphasis on identification of the concept of urban tissue (Kropf, 2013; Oliveria, 2016) also known as urban fabric.

In accordance to the recognized forms derived from the process typological approach that are conceived as 'cultural entities rooted in' (Kropf, 2009), the local processes of development, change and diversification on the other hand, resulted to the distinction of such forms with a generic similarity to the process closely associated with derivation. Extending the established understanding of the logical connection between different hierarchical levels in Caniggia's work, the first part formulates the identification of the most relevant level of analysis according to Kropf's taxonomy of urban form to determine the perspectival synthesis of urban morphological analysis. The proposed framework 
PLANNING MALAYSIA

Journal of the Malaysia Institute of Planners (2018)

provides a critical tool to allow the investigation of the diversity of built form and construct more rigorous and nuanced explanation in explaining the process of formation and transformation. Table 1 and Table 2 show the logical connection and simplify the taxonomy.

Table 1: Synthetic model of relationship

\begin{tabular}{lcccc}
\hline $\begin{array}{l}\text { Elements of } \\
\text { Urban Fabric }\end{array}$ & Plot (P) & Street (S) & $\begin{array}{c}\text { Constructed } \\
\text { Space }(\mathrm{CS})\end{array}$ & $\begin{array}{c}\text { Open Space } \\
(\mathrm{OS})\end{array}$ \\
\hline Plot (P) & $\mathrm{P} / \mathrm{OS}$ & $\mathrm{S} / \mathrm{OS}$ & $\mathrm{CS} / \mathrm{OS}$ & $\mathrm{OS} / \mathrm{OS}$ \\
Street $(\mathrm{S})$ & $\mathrm{P} / \mathrm{CS}$ & $\mathrm{S} / \mathrm{SC}$ & $\mathrm{CS} / \mathrm{CS}$ & $\mathrm{CS} / \mathrm{CS}$ \\
Constructed & $\mathrm{P} / \mathrm{S}$ & $\mathrm{S} / \mathrm{S}$ & $\mathrm{CS} / \mathrm{S}$ & $\mathrm{OS} / \mathrm{S}$ \\
Space $(\mathrm{CS})$ & & & & \\
$\begin{array}{l}\text { Open Space } \\
\text { (OS) }\end{array}$ & $\mathrm{P} / \mathrm{P}$ & $\mathrm{S} / \mathrm{P}$ & $\mathrm{CS} / \mathrm{P}$ & $\mathrm{OS} / \mathrm{P}$ \\
\hline
\end{tabular}

Source: Adapted from Levy (1999)

*Note: The highlighted column signifies the relationship between Constructed Space (CS) (or referred to buildings, i.e group of building in city block in the context of this research) to Open Space (OS) playing an important role in the formation of the urban landscape, presented as a relationship between private space and public space.

Table 2: Interpretation of Kropf's Taxonomy of built form

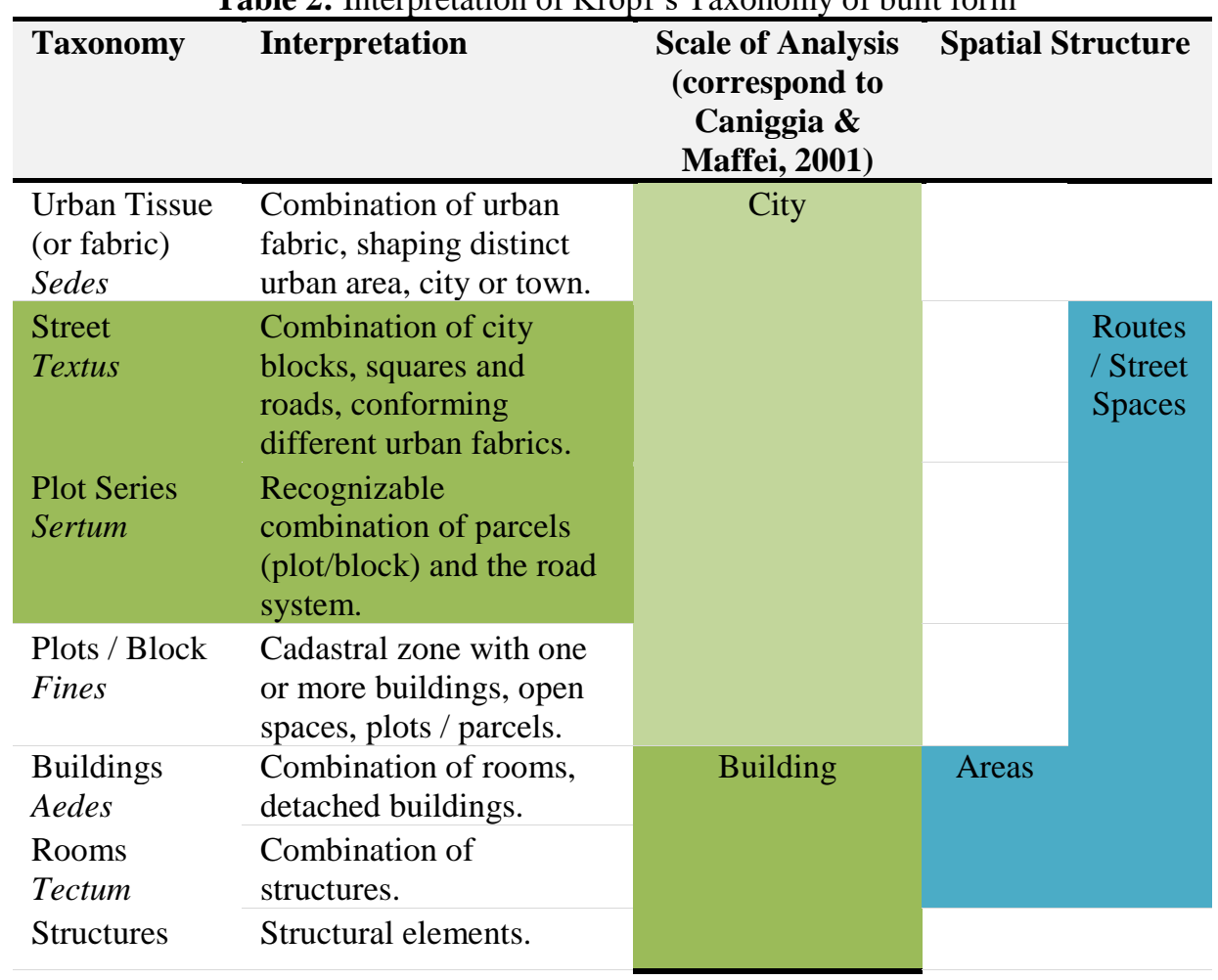


Syahidah Amni Mohamed, Nor Zalina Harun \& Alias Abdullah

Urban Morphological Analysis Framework for Conservation Planning and Management

\section{Statio}

Materials Construction materials.

Materia

*Note: The representatives of Latin names in taxonomy following Saraiva (n.d) seek to rule out any ambiguitie of language around the built environment observed, noting similarities with the framework developed by Caniggia.

Source: Adapted from Osmond (2010) \& Saraiva (n.d.)

\section{Urban Form Complexes to Determine the Spatial Urban Landscape Unit According to Morphogenetic Process}

The hierarchical structure of the city levels also quite explicit within the historicogeographical approach, a fundamental to Conzen's work (1960). In reference to the seminal study of town-plan analysis of Alnwick and Ludlow, the analysis conducted at extended to reveal the existence of physical form and transformation layout of the town as well as how the various components of that layout fitted together. This is based on distinguishing five general aspects of: (i) Site; (ii) Function; (iii) Townscape; (iv) Social and economic context; and (v) Development. Emphasizing to trace the character of historic city, the layout of the town were disaggregated and mapped according to three form complexes consisting of significant unitary areas, that are: (i) Town-plan or plan type areas, referring to areas delimited according to ground plan composing of street system, plot pattern and building pattern combining as plan-units; (ii) Land Utilization Pattern, referring to land and building utilization areas; and (iii) Building Fabric or building type areas focusing on the 3-dimensional physical form of the building (Kropf, 2009).

This approach provided an important opportunity to advance the understanding by articulating the ways of the development of those particular form complexes in each established unitary areas as being an integral part to the patterns delineated. Central to this, the analytical framework underpinned the significant integration of the historicity of the urban landscape, often termed as historical expressiveness whose importance expanded to uncover the societal values permeated in reference to 'morphogenetic priority' (Whitehand, 2007; Whitehand \& Gu, 2010). This priority reflects the relative resistance to changes of the elements that comprise each form complexes in order to determine the landscape unit. For instance, ground plan of street patterns tend to have high resistance as compared to land and building utilization which is more ephemeral as well as buildings, are on average intermediate in their resistance to change.

Thus, focusing on the Conzen's townscape aspect as the physiognomy of urban landscape, the characteristic of the town can be identified as comprising the physical configuration of the spatial patterns. This produces a consistent representation with a composite view of complementary elements according to different morphological period. The occurrence of different morphological periods imparted to the townscape known figuratively as historical layering and 
PLANNING MALAYSIA

Journal of the Malaysia Institute of Planners (2018)

point out to the historical development involved in creation of such distinctive townscape character. Conzen describes morphological regions as areas of having homogenous urban form in terms of land use, building type and plan type which can be distinguished from other surrounding areas in four levels within the hierarchical system, ranked as: (i) Morphotopes; which shows the basic historical elements and development with adaptive processes; (ii) First settlement areas and old development characterized by transformative processes; (iii) Combination of old and new development areas which involves the process of repletion; and (iv) New development areas represented by additive processes. All of these ranked levels create a basis for townscape that signifies the characteristics of each timelayer of the historical town. Table 3 illustrates the general conceptual of the integrated approach.

Table 3: The integrated approach according to Kropf's Taxonomy of built form and its correlation with Conzen and Caniggia

\begin{tabular}{|c|c|c|}
\hline $\begin{array}{l}\text { Kropf } \\
\text { Taxonomy }\end{array}$ & $\begin{array}{c}\text { Historico-Geographical } \\
\text { Approach / M.R.G Conzen } \\
\text { (Townscape) }\end{array}$ & $\begin{array}{c}\text { Process Typological } \\
\text { Approach / G. Caniggia (Co- } \\
\text { presence) }\end{array}$ \\
\hline $\begin{array}{l}\text { Urban } \quad \text { Tissue } \\
\text { Sedes }\end{array}$ & $\begin{array}{l}\text { Plan Division / Fringe belt / } \\
\text { Morphological Region }\end{array}$ & Urban Organism \\
\hline $\begin{array}{l}\text { Street } \\
\text { Textus }\end{array}$ & $\begin{array}{l}\text { Townscape } \\
\text { - Land Utilisation Pattern } \\
\text { - Plan Unit } \\
\text { - Building Fabric }\end{array}$ & $\begin{array}{l}\text { Urban Tissue (or Fabric) } \\
\text { - Lot } \\
\text {-Pertinent Strip } \\
\text { - Route }\end{array}$ \\
\hline $\begin{array}{l}\text { Plot Series } \\
\text { Sertum } \\
\text { Plots / Block } \\
\text { Fines }\end{array}$ & $\begin{array}{l}\text { Town Plan } \\
\text { - Street System } \\
\text { - Plot System } \\
\text { - Building Pattern }\end{array}$ & $\begin{array}{l}\text { - Block } \\
\text { - Infill / Base Tissues } \\
\text { - Node and Poles }\end{array}$ \\
\hline $\begin{array}{l}\text { Buildings } \\
\text { Aedes }\end{array}$ & & \multirow[t]{4}{*}{ Buildings } \\
\hline $\begin{array}{l}\text { Rooms } \\
\text { Tectum }\end{array}$ & & \\
\hline $\begin{array}{l}\text { Structures } \\
\text { Statio }\end{array}$ & & \\
\hline $\begin{array}{l}\text { Materials } \\
\text { Materia }\end{array}$ & & \\
\hline
\end{tabular}

Source: Adapted and Revised from Saraiva (n.d.)\& Comert (2015). 
Syahidah Amni Mohamed, Nor Zalina Harun \& Alias Abdullah

Urban Morphological Analysis Framework for Conservation Planning and Management

\section{DISCUSSION}

The establishment of the framework and spatial units of urban growth represented by city block reflects a shared understanding of the integrated approaches whose concept could be applied with urban conservation practice. As identified by Nikovic, Dokic and Maric (2014), the key characteristics of morphological analysis are contained within the urban entity of urban block, which can be considered as a basic generative elements and generic features of cities reflected by its physically static component to reveal the transformation of urban structure in historical towns. Dokic (2007) further emphasis the idea on urban block as constituent elements of an urban space which had a significant influence in morphological analysis. By performing a comparative analysis of methodological approaches, this research generally follows the Conzenian cognitive approach with a combination of Caniggia's dialectic relationship of typological process as illustrates in Figure 1. The theoretical account of the methodology developed considering the socio-spatial character of Malay Early towns for apprehending their specificities. This study anticipated to offer some important insight on unifying approaches of morphological analysis with a shared representation of urban block as spatial units that signify the establishment of interrelationship between different hierarchical scales to facilitate more purposeful application of urban morphology in conservation planning and management of Early Malay towns.

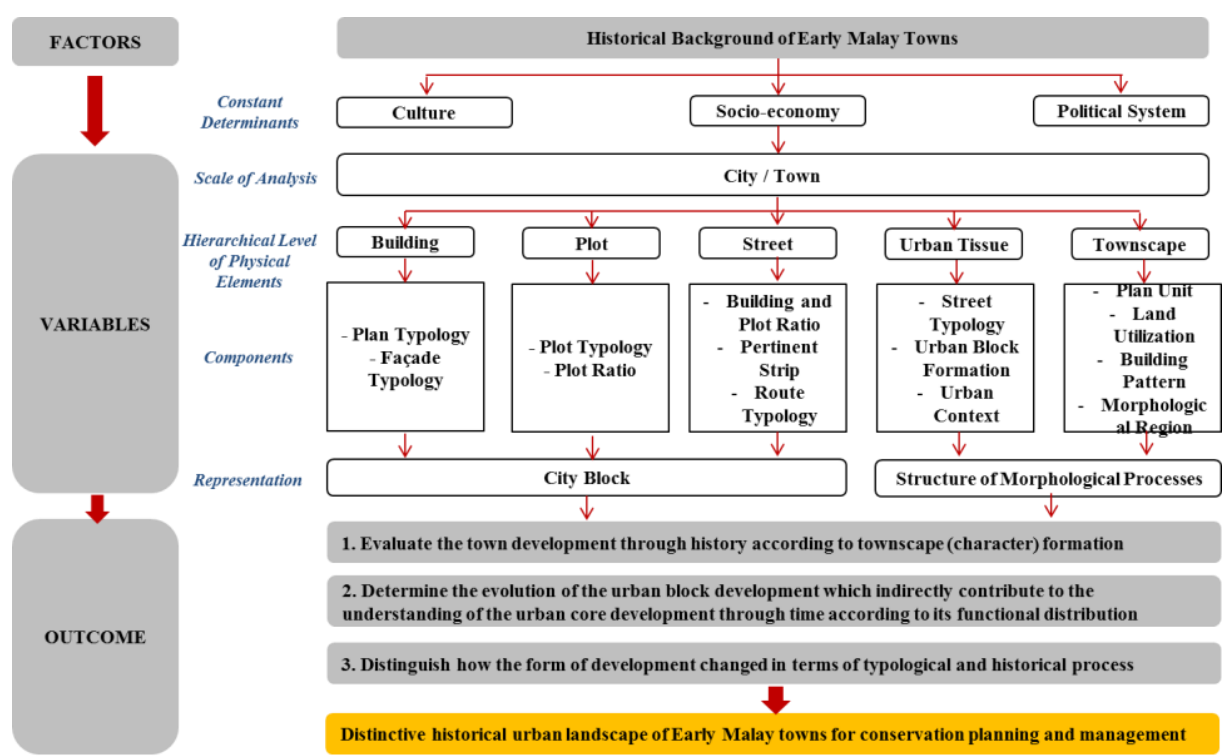

Figure 1: Conceptual framework for morphological analysis of early Malay towns with key representation of city block derived from the integrated approach of process typological (according to Caniggia) and historico-geographical (according to Conzen). 


\section{CONCLUSION}

The form of the city is the physical manifestation of its identity that contributes to a better understanding of the urban reality of the place. Such deficiency in morphological understanding that mirrors the evolutionary dynamics of the city as a mosaic of urban formation in planning and design will lead to the dysfunctional of the city; peering into its relations with the surrounding urban fabric. The research revealed the representation of urban block as a basis of the morphogenetic method typical of any approaches either in Conzenian and Caniggian tradition that served as the backbone to connect the spontaneous and planned forms of settlements. In line with this, the research recommended that further investigation on the underlying of the indices in developing the integrated framework should receive more attention with regard to both physical and nonphysical characteristics for evaluation in each hierarchical scale of urban form analysis.

\section{ACKNOWLEDGEMENT}

The authors would like to express their sincere gratitude to the Ministry of Higher Education Malaysia (MOHE) in the support of this research. This research is funded by the Transdisciplinary Research Grant Scheme (TRGS) for research project code TRGS16-03-002-0002.

\section{REFERENCES}

Caliskan, O., \& Marshall, S. (2011). Urban morphology and design: Introduction. Built Environment, 37(4), 381-392.

Caniggia, G., \& Maffei, G. (2001). Architectural Composition and Building Typology: Interpreting basic building (S. J. Frazer, Trans.). Firenze, Italy: Alinea Editrice.

Cataldi, G., Maffei, G. L., \& Vaccaro, P. (2002). Saverio Muratori and the Italian school of planning typology. Urban Morphology, 6(1), 3-14.

Comert, N. Z. (2013). Testing an integrated methodology for urban typo-morphological analysis on Famagusta and Ludlow (Doctorate dissertation). Eastern Mediterrenean University, Cyprus.

Conzen, M. R. G. (1960). Alnwick, Northumberland: A study in town-plan analysis. Transactions and Papers (Institute of British Geographers), 27, 3-5.

Crowther, P. (2016). Morphological analysis of the city for achieving design for disassembly. WIT Transactions on Ecology and the Environment, 204, 15-26.

Dibble, J., Prelorendjos, A., Romice, O., Zanella, M., Pagel, M., \& Porta, S. (2015). Urban morphometrics: Towards a science of urban evolution. In G. Strappa, A. R. Amato, \& A. Camporeale (Eds.), City as organism: New visions for urban life. Rome, IT:(U+D) Edition 14.

Dokic, V. (2009). Morphology and typology as a unique discourse of research. Serbian Architectural Journal, 1(2), 107-130. 
Syahidah Amni Mohamed, Nor Zalina Harun \& Alias Abdullah

Urban Morphological Analysis Framework for Conservation Planning and Management

Gauthier, P., \& Gilliland, J. (2006). Mapping urban morphology: A classification scheme for interpreting contributions to the study of urban form. Urban Morphology, 10(1), 41-50.

Kong, L., \& Yeoh, B. S. A. (1994). Urban conservation in Singapore: A survey of state policies and popular attitudes. Urban Studies, 31(2), 247-265.

Kropf, K. (1993). The definition of built form in urban morphology (Doctorate dissertation). University of Birmingham, UK.

Kropf, K. (2009). Aspects of urban form. Urban Morphology, 13(2), 105-120.

Kropf, K. (2011). Urbanism, politics and language: The role of urban morphology. Urban Morphology, 15(2), 157-162.

Kropf, K. (2013). What is urban morphology supposed to be about? Specialization and the growth of a discipline. Urban Morphology, 17(2), 128-131.

Levy, A. (1999). Urban morphology and the problem of the modern urban fabric: Some questions for research. Urban Morphology, 3(2), 79-85.

Lovra, E. (2016, April). The modern city: Urban tissue typology (Limitations of Caniggian and Conzenian practice and the new typology). 4th International Conference on Contemporary Achievements in Civil Engineering. April 22, 2016, Subotica, Serbia.

Marshall, S. (2015). An area structure approach to morphological representation and analysis. Urban Morphology, 19(2), 117-134.

Moudon, A. V. (1994). Getting to know the built landscape: Typomorphology. In K.A. Franck, \& L. H. Schneekloth (Eds.), Ordering Space: Types in Architecture and Design (pp. 289-311). New York: Van Nostrand Reinhold.

Moudon, A.V. (1997). Urban morphology as an emerging interdisciplinary field. Urban Morphology, 1(1), 3-10.

Nikovic, A., Dokic, V., \& Maric, I. (2014). Revising the position of a city block within the morphological frame of a traditional city: Contemporary perspectives. SPATIUM International Review, 1(31), 1-6

Oliveria, V. (2013). Morpho: A methodology for morphological analysis. Urban Morphology, 17(1), 149-161.

Oliveria, V. (2016). An introduction to the study of the physical form of cities. S.1.: Springer.

Osmond, P. (2010). The urban structural unit: Towards a descriptive framework to support urban analysis and planning. Urban Morphology, 14(1), 5-20.

Ravari, A. A., \& Mazloomi, M. (2015). A framework for urban morphology with respect to the form. Armanshahr Architecture \& Urban Development, 8(4), 91-103.

Saraiva, A. F. P. (n.d). The morphological analysis as a support for urban planning: the case study of the Gate of Carcais. Retrieved from https://fenix.tecnico.ulisboa.pt/downloadFile/844820067123327/Ext_abstract_ FINAL.pdf

Said, S. Y., Aksah, H., \& Ismail, E. D. (2013). Heritage conservation and regeneration of historic areas in Malaysia. Procedia - Social and Behavioral Sciences, 105, 418428.

Shamsuddin, S. (2011). Townscape revisited: Unravelling the character of the historic townscape in Malaysia. Johor Bahru: Penerbit UTM Press. 
PLANNING MALAYSIA

Journal of the Malaysia Institute of Planners (2018)

Whitehand, J. W. R. (2007, June). Conzenian urban morphology and urban landscape. $6^{\text {th }}$ International Space Syntax Symposium. June 12-15, 2007, Istanbul, Turkey.

Whitehand, J. W. R., \& Gu, K. 2010. Conserving urban landscape heritage: A geographical approach. Procedia - Social and Behavioural Sciences, 2, 69486953. 